\title{
Swaardmag en lyding - oor die reformatoriese perspektief op staatsgeweld
}

\author{
M.F. Heyns \\ Departement Filosofie \\ Potchefstroomse Universiteit vir $\mathrm{CHO}$ \\ POTCHEFSTROOM
}

\begin{abstract}
The power of the sword and suffering: on the Reformational view of state violence

The nature of violence demands, as a general norm, a basic objection to violence. Special circumstances may, however, allow for the legitimation of violence. This position is abolished in the legitimist view of violence which justifies, per definition, the violence of people in positions of authority. The metaphysics grounding such a move implies, inter alia, Platonic ontologised ideas or realism which gives a timeless, supernatural, unchangeable position to the power of the sword. Although the Reformational position seems to be legitimistic in nature, this tradition does not use a Platonic realism and therefore does not elevate state violence to a timeless structural moment of the state. It is also argued that state violence should get an underemphasized position within the structure for the state: although the power of the sword is given to the state for functional reasons, it does not mean the state can not, and indeed should dispose of the power of the sword if circumstances permit. Lastly, it is also argued that the apparent tension hetween the basic objection to violence and legitimized violence can only be resolved in some higher ideal like the biblical concept of redemption as restoration.
\end{abstract}

\section{Inleiding}

\subsection{Agtergrond}

Woordeboekdefinisies lê klem op drie dimensies van geweld, naamlik dat geweld (a) 'n fisiese gebruik van (b) mag/krag/dwang is met (c) die bedoeling om te beskadig of beseer (vergelyk die Handwoordeboek van die 
Swaardmag en lyding - oor die reformatoriese perspektief op staatsgeweld

Afrikaanse Taal, Concise Oxford Dictionary, Reader's Digest Universal Dictionary).

Op die oog af lyk dit of die beoordeling van geweld veral betrekking het op die derde dimensie, naamlik die bedoeling om te beskadig of te beseer. Hierdie kenmerk noop Edgley (1974:134) byvoorbeeld om te stel dat die inherente aard van geweld dit noodsaak dat daarteen geargumenteer moet word. Die tweede dimensie, naamlik mag/krag, kan egter ook negatief beoordeel word as geweldsmag per definisie gesien word as iets wat die regmatige mag ontneem van diegene wat geweld aangedoen word. Garver (1970:354-356) is byvoorbeeld van oordeel dat geweld primêr mag is wat ingryp op ' $n$ persoon se outonomie en waardigheid en Galtung (1969:168) is die mening toegedaan dat geweld persone verhoed om hul liggaamlike en mentale potensiaal in werking te stel. Ook binne reformatoriese kring word sterk klem gelê op die siening dat geweld magsmisbruik impliseer magsmisbruik waardeur die geweldenaar die roepingsvervulling van die geweldsonderworpene onmoontlik maak (Heyns, 1989:192-193; Van der Walt 1990:1-2; Van Wyk, 1990:77; Venter, 1984:87).

Die eerste dimensie van geweld, naamlik die fisiese aspek daarvan, veronderstel ook 'n ingeboude waardeoordeel ten spyte daarvan dat sommige mense reken dat die fisiese aspek die neutrale/beskrywende element in die definiëring van geweld is. Coady (1986:4) byvoorbeeld, wat die fisiese dimensie as die neutrale/beskrywende komponent sien, argumenteer wel in sy oorhoofse uitgangspunt oor die definiëring van geweld dat ons in enige definisie van geweld te doen het met ' $n$ "complex interplay between concept and commitment" en dat die fisiese definisie 'n natuurlike affiniteit met 'n reformisties-liberaal-politiese visie het'. Die punt is dit: die drie dimensies van geweld vorm 'n geheel en geeneen kan van die ander geïsoleer word ter wille van 'n gewaande poging tot neutraliteit/objektiwiteit nie. Geweld word in sy wese be(ver)oordeel deur die norm wat, by 'n gebrek aan 'n beter formulering, as die basiese beswaar teen geweld geformuleer kan word.

I Dieselfde paradoks is te vinde by Degenaar (1990:70) en Du Toit (1991:120) wat daarop aandring dat die deskriptiewe en normatiewe komponente van geweld nie in die geweldsdefinisie vermeng mag word nie en dat met 'n deskriptiewe (fisiese) definisie begin moet word. Tegelyk gaan hul egter van die standpunt uit dat geweld iets is wat in sy wese ' $n$ paradigmageval van boosheid is en altyd vra om geregverdig/gelegitimeer te word indien dit gebruik word (Degenaar, 1990:70, 74, 84 \& Du Toit, 1990:109). 
Ten spyte van die basiese beswaar teen geweld wat hy opmerk, meen Edgley (1974:134) tog dat omstandighede soms die gebruik van geweld kan noodsaak. Vir hom beteken dit dat die basiese beswaar teen geweld altyd een argument tussen ander oor geweld is maar beslis nie die finale (conclusive) argument is nie. Hierdie ervaring van die bestaan en beoordeling van geweld lyk op die oog af spanningsvol: daar is 'n plek vir geregverdigde geweld maar tegelyk is geweld per definisie te veroordeel en moet dit dus altyd met skeptisisme bejeën word.

\subsection{Probleemstelling}

Die basiese vraag van hierdie artikel handel oor die wyse waarop die reformatoriese standpunt die basiese beswaar teen geweld verreken - veral in sy legitimering van politieke geweld. Anders gestel: hoe word die oënskynlike spanning tussen die basiese beswaar teen geweld en gevalle van geregverdigde geweld opgehef? Dit is opmerklik dat die onderliggende bedoeling van vele reformatoriese denkers inderdaad is om die basiese beswaar teen geweld onverdund te handhaaf. Die oorwegende beklemtoning is om te stel dat hoewel nie van 'n pasifistiese standpunt uitgegaan word nie, 'n Christen geweld moet afkeur en dat iets soos verset niegewelddadig behoort te wees (Van der Walt, 1990:169; Van Wyk, 1990:85-86; Heyns, 1989:174, 198, 216-217). Ook behoort 'n regering wat tot die nadeel van sy burgers regeer (dus geweldprovokerend optree), veroordeel en tot verandering opgeroep word (Van der Walt, 1990:163, 165, 167, 169; Van Wyk, 1990:89-92; Heyns, 1989:133-134).

'n Geweldsbeskouing wat prominent in reformatoriese kringe voorkom, is die standpunt dat persone in gesagsposisies 'n geweldsmonopolie het. Met die basiese beswaar teen geweld in die agterkop, sal sommige mense probeer om die fundamentele spanning rondom geweld te ontkom deur te stel dat die geregverdigde uitoefening van geweld deur regeringsagente nie as 'geweld' getipeer kan word nie. As 'n rower met 'n vuurwapen op die polisie skiet en die polisie skiet terug, is die rower se aksie geweld, maar die polisie is hoogstens besig met gesagsuitoefening (Heyns, 1989:193). Ook wanneer verset en rewolusie ter sprake kom, sal die reformatoriese standpunt steeds klem daarop lê dat die rewolusie-agente mense in gesagsposisies moet wees of "mense uit wie daar reeds 'n potensiële alternatiewe regering aan die ontwikkel is" moet wees wat "die proses in beheer kan hou" (Heyns, 1989:217). 
Swaardmag en lyding - oor die reformatoriese perspektief op staatsgeweld

Hierdie tipe geweldslegitimering lyk met die eerste oogopslag na dit wat bekend geword het as die legitimistiese siening van geweld ${ }^{2}$. Hiervolgens is die wettigheid/onwettigheid van die outoriteit wat die geweld uitvoer, sentraal.

* Die eerste probleem met hierdie strategie is dat 'n kriterium vir die wettigheid van die outoriteit 'n uiters kontroversiële aangeleentheid is $^{3}$.

* Tweedens, hierdie siening kan op 'n drogredenasie afstuur: sekere gegewens kry in die definisie vir geweld sodanige prominensie dat ander relevante gegewens verdring word: die omstandighede van die geweldsagent (sy gedefinieerde reg tot geweld) word in die definiëring van geweld belangriker geag as die basiese beswaar teen geweld. Sodoende word 'n norm wat 'n beperkende invloed op geweld kon wees, buite spel geplaas.

* Laastens is dit duidelik dat veral 'n Platoniese metafisika van tydlose, onveranderlike idees/ideale wat as 'n verontologiseerde realiteit aangebied word, 'n vernietigende verskansing van geweld tot gevolg kan hê. Hiervolgens kan staatsgeweld deel vorm van 'n tydlose, onveranderlike struktuur vir die staat binne die tradisie van die metafisiese realisme.

Hierdie agtergrondraamwerk vir geweld kan die basiese beswaar teen geweld grootliks verduister en sodoende 'n belangrike onderbou vir 'n legitimistiese geweldsiening bied. Die vraag is natuurlik of dit geregverdig is om die breë reformatoriese denktradisie se siening van geweld tot legitimisme te reduseer op grond van die uitsprake wat hierbo aangehaal is. Vanuit filosofiese perspektief is veral ter sake die vraag of die staat se reg op die swaardmag ondersteun word deur 'n metafisiese realisme. Nog belangriker is die vraag of dit hoegenaamd moontlik is om tegelyk vas te

2 Vir 'n oorsig oor die verskillende strategieë vir die legitimering van geweld, vergelyk Chidester (1992:x-xii) en Heyns (1994:95-107). Dit blyk dat minstens vyf sodanige strategieë tans populêr is, naamlik die engere, wye, middel-doel, legitimistiese en naturalistiese sienings.

3 Coady (1986:13-14) lê met 'n voorbeeld sy vinger op die probleem: hoe gemaak in die geval van twee legitieme outoriteite soos byvoorbeeld twee regerings wat in 'n oorlog gewikkel is? Volgens die legitimistiese definisie is hier nie van geweld sprake nie, ten spyte daarvan dat dit moontlik is dat die twee lande mekaar met atoombomme die ewigheid kan instuur. 
M.F. Heyns

hou aan die basiese beswaar teen geweld en die erkenning van die geldigheid van die swaardmag van die staat as albei sienings norme vir die funksionering van die staat impliseer.

\section{2. 'n Raamwerk vir die interpretasie van die basiese beswaar teen geweld}

\subsection{Die moderne historisme en die stryd teen lyding}

Die basiese beswaar teen geweld moet teen die agtergrond van 'n fundamentele kontemporêr-kulturele motief gesien word, naamlik die stryd teen lyding, pyn en vernedering. Een van die bekendste huidige eksponente van hierdie motief is Richard Rorty (1993:xv, 74, 146) vir wie die ideale mens 'n liberal ironist is. In hierdie ideaalbeeld vir menswees dui die liberal komponent van sy dualisme op "people who think that cruelty is the worst thing we do" (Rorty, 1993:xv). 'n Tweede bekende NoordAmerikaanse filosoof, naamlik Charles Taylor (1989:12-14), wys daarop dat die moderne Weste se klem op die vermyding van lyding een van die mees prominente huidige artikulasies van kulturele ideale is. Die idee dat lyding tot 'n minimum beperk moet word, is vandag 'n integrale deel van wat dit beteken om die lewe van 'n ander te respekteer: ons is immers baie meer as ons voorouers sensitief hiervoor - ons sal byvoorbeeld met afgryse na hul maniere van straf as barbaars verwys.

Hierdie ideaal is egter nie sonder 'n angel nie. Rorty (1993:xiii-xvi) stel met die ironist-deel van sy tweeledige/dualistiese ideaal vir menswees 'n soort persoon voor "who faces up to the contingency of his or her own most central beliefs and desires - some-one sufficiently historicist and nominalist to have abandoned the idea that those central beliefs and desires refer back to something beyond the reach of time and chance" (Rorty, 1993:xv). Rorty maak selfs daarop aanspraak dat die historisme ons bevry het van die metafisiese en teologiese pogings om van tyd en kans te ontsnap: daar bestaan eenvoudig nie so 'n orde wat 'n voorskrif kan gee vir 'n hiërargie van verantwoordelikhede nie.

Dit is tevergeefs om Rorty daarvan te beskuldig dat die stryd teen lyding en vir menslike solidariteit ' $n$ universele aanspraak maak wat sy siening weerspreek dat die mens deur en deur histories, kontingent en selfskeppend is. Hy aanvaar en lyk selfs trots op hierdie paradoks. Saam gesien, veronderstel 'liberaal' en 'ironis' volgens Rorty (1993:xv-xvi, 7374) dat wat hierdie aspek betref, ons te doen het met iemand wat nie 'n 
Su'aardmag en lyding - oor die reformatoriese perspektief op staatsgeweld

antwoord kan gee op die vraag waarom die verset teen wreedheid en lyding (universeel) nagestreef behoort te word nie. Die hoop dat lyding verminder sal word en dat die vernedering van mense deur ander mense sal ophou, is een van die moderne mens se onbegrondbare fundamentele begeertes. Rorty (1993:xiii-xiv) meen dat dit nie anders kan as dat 'n onoplosbare tweedeling binne die kontemporêr-historistiese mensbeskouing bestaan nie. Die ironis in wie die begeerte na selfskepping en persoonlike outonomie oorheers, is van oortuiging dat daar nie so iets soos menslike solidariteit kan bestaan nie. Hierteenoor beskryf liberale historiste in wie die begeerte na 'n meer regverdige en vrye menslike gemeenskap oorheers die begeerte na persoonlike selfskepping as irrasionalisme en estetisisme. Volgens Rorty is daar geen manier om selfskepping en (universele) geregtigheid in dieselfde teorie te kombineer nie. Tegelyk egter, sê hy, moet reg geskied aan albei beklemtoninge - maar dan nie met 'n poging om albei standpunte in 'n enkele visie vas te gryp nie.

Laasgenoemde aanspraak van Rorty, naamlik dat hy ironist en liberal nie koppel nie, lyk egter verdag. Rorty (1993:xiii \& xvi) boor tot die wortel van sy eie en ons kultuur se vooronderstellings as hy sê dat die belangrikste voordeel wat die historisme vir hom inhou die feit is dat dit die soeke na waarheid vervang het met 'n soeke na vryheid. Geertsema (1991:59-60) is van mening dat Rorty se diepste uitgangspunt 'kontingensie' is - 'n uitgangspunt wat tegelyk niks anders as die ideaal van bevryding is nie. Die interessante van kontingensie as uitgangspunt is dat dit veronderstel is om sowel ironie as solidariteit te dek. Dit is oënskynlik die geval met ironie maar solidariteit vereis tog dat aan 'n kontingente tipe vryheid 'n grens gestel word: "Maar kennelijk is er toch iets in de mens, het vermogen pijn te lijden en vernederd te kunnen worden, dat voor Rorty algemeengeldigheid bezit" (Geertsema, 1991:60). Wanneer die verhouding tussen historisme en solidariteit/stryd teen lyding ietwat anders gestel word, kom 'n belangrike saak in fokus: nominalisme en historisme word slegs moontlik as die konstante van die werklikheid beperk word tot die ideaal van die stryd teen lyding. Taylor (1989:12-14) wys daarop dat die stryd teen lyding as motief inderdaad na vore tree na afloop van die agteruitgang van die idee van 'n kosmiese morele orde waarin onder andere veronderstel is dat 'n vreeslike misdaad met 'n ewe verskriklike straf gelyk gestel moet word. Die beklemtoning van die stryd teen lyding het gegroei namate die idee getaan het dat die mens 'n rol te speel het in ' $n$ kosmiese orde of ' $n$ goddelike geskiedenis. Die punt is dit: die kontingente en die vaste is nie so ongekoppel as wat Rorty voorgee nie. 
M.F. Heyns

Nog anders gestel: dis nie moontlik om vryheid/kontingensie absoluut te stel sonder dat waarheid by die agterdeur inglip nie.

Hiermee raak Rorty en Taylor aan sekerlik een van die belangrikste kwessies binne die moderne meta-etiek, naamlik die vraag na universeel geldende norme. Die gevolg van die oorweldigende invloed van die moderne historisme is die siening dat alle morele norme volledig kultuurrelatief is. Die onhoudbaarheid van hierdie standpunt in sy radikale vorm word weerspieël in die paradoksale/dualistiese manier waarop universele norme die standpunt van byvoorbeeld Rorty insluip. ${ }^{4}$ Die uitdaging aan ' $n$ omvattende etiek is daarom om die oorweldigende siening van die kulturele relatiwiteit van normstelsels met die aandrang op 'n universele erkenning van basiese morele norme te versoen.

Die onderskeid van Taylor tussen morele instinkte/intuïsies en die kultuurrelatiewe artikulering daarvan kan as so 'n 'omvattende' poging beskou word. Volgens Taylor (1989:15-16) is daar drie instinkmatige of intuïtiewe dimensies waarbinne morele denke en beoordeling plaasvind naamlik: (i) die respek vir die lewe van ander mense, (ii) 'n verstaan van wat aan 'n mens 'n vol lewe gee, en (iii) die waardigheid van die mens. Hierdie drie dimensies is 'n fundamentele gegewe; 'n bewustheid daarvan bestaan in feitlik elke kultuur. Wat wel aan kulturele verandering onderworpe is, is die interpretasie/artikulasie daarvan. Hiervolgens kan die drie dimensies se verhouding tot mekaar van tyd tot tyd verander; veral ten opsigte van watter van hierdie dimensies leidende belangrikheid in 'n bepaalde kultuur inneem. Daarbenewens is nuwe raamwerke, agtergrondprentjies, morele horisonne of artikulasies van die inhoud van hierdie dimensies gedurig aan't ontwikkel. Meer spesifiek verduidelik Taylor (1989:25-26) dat sodanige artikulasies die tydgebonde antwoord is op die vrae wat implisiet in die drie morele dimensies aanwesig is.

Hierdie teoretiese verduideliking onderlê Taylor $(1989: 4-5,11-16,84)$ se siening dat die huidige moderne Westerse kultuur een morele dimensie benadruk as die belangrikste, naamlik die aandrang op die respek vir die

4 Vergelyk ook die volgende uitspraak van Geertsema (1991:60): "Rorty is een exponent van het denken in de moderne Westerse samenleving, waarin universele maatstaven word afgewezen, omdat daarvoor geen fundament meer te vinden is, maar waar toch nog aan bepaalde waarden en normen word vastgehouden. De betekenis van Rorty ligt m.i. vooral daarin dat de konsekwenties van dit denken radikaal zichtbaar worden gemaakt." 

'n universele verbod geplaas op die doodmaak van ander, die steel van hul besittings, intimidasie ensovoorts. Een van die kenmerkende huidige artikulasies van hierdie morele dimensie is die belangrike plek wat gegee word aan die vermyding van lyding. Hiermee gee Taylor minstens vir ons ' $n$ visie op die vermyding van lyding - waaronder dan ook die basiese beswaar teen geweld - as iets wat nie noodwendig getipeer hoef te word as 'n 'onbegrondbare begeerte' (Rorty) nie. Anders gestel, die basiese beswaar teen geweld spruit nie outomaties uit 'n werklikheid waar kans en verandering ongebreideld heers nie.

Binne die reformatoriese filosofie word lank reeds gebruik gemaak van die onderskeiding tussen skeppingsbeginsels wat as 'n uitdrukking van God se universele wil vir die saamleef van mense gesien word, en gepositiveerde norme wat die kultuurrelatiewe formulering is van hierdie skeppingsbeginsels. Op grond van die stryd teen lyding het hierdie formulering by sommige filosowe egter onlangs ' $n$ interpretasie ondergaan wat in 'n Rortyaanse rigting neig.

\subsection{Die reformatoriese siening van skeppingsorde en die stryd teen lyding}

Volgens Henk Hart (1992a:1-2) kan 'orde' nie die sentrale konsep binne die reformatoriese tradisie wees nie maar wel 'n etos van mededoë/barmhartigheid. Hierdie ethos of compassion dui op 'n selfopofferende liefde teenoor veral die naaste en skepping - 'n etos wat die reaksie behoort te wees op die Goddelike bevryding van die skepping. 'n Mens kan nie anders as om die weerklank van die moderne motief van stryd teen lyding en ter wille van bevryding in hierdie etos raak te sien nie.

Hierdie indruk word versterk as ethos of compassion positief verbind word aan 'n wantroue jeens die tradisionele reformatoriese konsep skeppingsorde. Volgens Hart (1992a:1-2) behoort die reformatoriese tradisie juis antirealisties te wees. Die motivering is naamlik dat 'n metafisika van realisme lyding vermeerder: volgens Hart (1992a:10-11) is orde-ontologieë die produk van 'n rede wat soek na die algemeenhede in die verskeidenheid en dit dan ontologiseer. In sy rigiede vorm beteken dit dat individualiteit, verandering, subjektiwiteit, historisiteit, uitsonderings en gemarginaliseerde mense uitgeskuif en geïgnoreer word. Hart (1992a:13-15) waardeer wat hierdie rede in die vorm van mag en vooruitgang vir die 
M.F. Heyns

Westerse kultuur gedoen het maar hy is dit met die Postmodernisme eens dat rede, mag en vooruitgang in 'n geloof van sy eie ontaard het. Hierdie eiesoortige geloof loop uit op die tirannisering deur tydlose absolutes en heersende magte van dit wat nie in die redelike prentjie/konsensus inpas nie. Wat meer is, die magte wat deur die rede lewe gegee is, naamlik die markekonomie, tegnologie ensovoorts, is besig om 'n momentum van sy eie te kry en sodoende totaal buite beheer van die mens te raak.

Teen hierdie agtergrond lyk dit asof daar ernstige vrae gevra kan word oor die tradisionele reformatoriese siening dat die swaardmag inherent tot die Goddelike orde vir die staat hoort. Dit blyk dat twee probleemareas noukeurige en genuanseerde aandag moet kry, naamlik of die reformatoriese erfenis inderdaad dié van 'n metafisiese realisme is en tweedens, indien 'n metafisiese realisme verwerplik is, watter rol historisiteit en konstantheid in die reformatoriese werklikheidsvisie behoort te kry.

Volgens Hart (1992a:3) het die Platoniese logostradisie wel die reformatoriese interpretasie van die wet as verbondsmetafoor binnegedring. Hart $(1992 \mathrm{a}: 8,12)$ is van mening dat hoewel een van die belangrikste eksponente van die reformatoriese tradisie, Herman Dooyeweerd (1955:237-241, $558-559 ; 1957: 2-5,7,10,283$ ), daarop aanspraak maak dat sy idee van die skeppingsorde iets anders is as die Platoniese tradisie, dit tog moeilik is om die verskil te sien in die konsepte wat Dooyeweerd gebruik. Hart het dit veral daarteen dat Dooyeweerd (1957:329) wil hê dat die beginsels van die skepping deur die rede nagespeur moet word; dit is altyd die verabsolutering van die teoretiese rede wat tot variante van die logostradisie lei. In dieselfde gees kritiseer Wolterstorff (1983:62) spesifiek Dooyeweerd se struktuur vir die staat: ons is dit nie in die eerste plek aan God verskuldig om die innerlike natuur en identiteit van 'n entiteit (byvoorbeeld die staat) na te speur en te ontsluit nie. Ons is dit egter wel aan God verskuldig om toe te sien dat die instellings van ons samelewing (byvoorbeeld die staat) "adequately serves the life of its members - that they serve the cause of justice and shalom" (Wolterstorff, 1983:62).

Volgens Hart/Wolterstorff behoort hierdie standpunt nie op 'n postmoderne relatiwisme uit te loop nie aangesien kriteria waarvolgens geleef word, steeds gestel en erken word. Hart (1992b:4) gaan selfs so ver as om te stel dat hy ook 'n konstantheid aan die Goddelike wet vir die kosmos wil sien. Hierdie konstantheid is egter nie van die wet se onveranderlikheid afhanklik nie maar van "the standing of God with the creature in the law" (Hart, 1992b:4). Laasgenoemde interpretasie van die 
Swaurdmag en lyding - oor die reformatoriese perspektief op staatsgeweld

wet is duidelik ook die bedoeling van Van der Hoeven (1992:1-2) hoewel hy reageer teen Hart se beskuldiging dat 'n a-tydse legalisme die reformatoriese tradisie oorheers. Hy wys daarop dat sowel Vollenhoven as Dooyeweerd die hart van die wet in die liefdeswet gesien het wat inderdaad iets anders is as 'n metafisiese orde'. Ook Wolters (1992:12) se oordeel oor Dooyeweerd is positiewer as dié van Hart hoewel hy erken dat Dooyeweerd se konsepte misleidend kan wees en die indruk van 'n metafisika kan skep. Tog hou hy vol dat sowel Dooyeweerd as Vollenhoven die onveranderlikheid van die skeppingswet losgemaak het van die tradisie van Christelike logosspekulasie en dit direk in die getrouheid van God gefundeer het. Hulle het daarom ook eerder van die konstantheid van die wet gepraat en dit sodoende, wat hy noem, 'n 'etiese' eerder as ' $n$ 'metafisiese' konsep gemaak.

Dus, hoe ook al oor die geslaagdheid van Dooyeweerd se wegbeweeg van die Griekse logostradisie geoordeel word, lyk dit wel of daar konsensus bestaan dat die rigting vir die reformatoriese tradisie 'n etiese eerder as 'n logosistiese interpretasie van die wet moet wees. Eties word hier gebruik met die betekenisveronderstelling dat die getrouheid van God en die welsyn van mense vooropstaan wanneer oor die wet gepraat word eerder as om dit met onveranderlike Platoniese konsepte in te kleur. Dit is teen hierdie agtergrond wat die inbou van die swaardmag in 'n goddelike struktuur vir die staat verstaan moet word. Die gebruik van die swaardmag deur die staat is nie 'n a-tydse opdrag wat van die situasie losgemaak is nie. Ook is dit nie ' $n$ opdrag wat vasgevries is in 'n metafisiese wêreldorde vir die staat nie. Die orde vir die staat is deel van God se saamwees met die mens in die stryd om die staatsinstelling te plooi tot ' $n$ instrument wat die welsyn van die mens dien.

5 Van der Hoeven beskuldig Hart daarvan dat hy Dooyeweerd se verwysings na die wet as tyds beskou en dat hy die feit ignoreer dat dit ' $n$ dinamiek verkry met die leer van analogiee en funksieontsluiting. Hoewel Hart (1992b:3-4) - in antwoord op kritiek teen sy interpretasie van Dooyeweerd - volhou met sy aanklag dat Dooyeweerd vashou aan 'n "absolutized general concept of reality", erken hy wel dat Dooyeweerd ' $n$ begin gemaak het om 'n logosentriese visie uit die wet te haal. Hierdie projek moet egter voltooi word. Die belangrike konsensus in die dispuut tussen Van der Hoeven en Hart is egter die standpunt van albei dat gefokus moet word op die bedoeling van Dooyeweerd se leer van die wet, naamlik om die arbitrêrheid van die outonome denke hok te slaan. 
M.F. Hey'ns

Hierdie verwerping van 'n metafisiese realisme werp onmiddelik die vraag op na die wyse waarop die historisiteit van die werklikheid dan volgens 'n reformatoriese siening geïnterpreteer moet word. Dooyeweerd (1957:381$384 ; 1979: 42,49,55-58,61-62$ ) self het hom fel verset teen die historisme wat hy as die "fatal illness of our 'dynamic' times" tipeer": Die idee van 'n konstante struktuur is belangrik om te verhoed dat 'n historistiesrelatiwistiese houding die botoon in die staatsteorie kry. Die vraag is egter of hierdie aandrang op konstantheid Dooyeweerd nie verlei tot 'n metafisiese realisme en die onvrye perspektiewe wat dit in die hand werk nie. Wolters (1992:15) oordeel dat Dooyeweerd se teorie van die ontsluitingsen differensiasieproses die effek het "... of making Neo-Calvinism much more open to historical progression than orthodox Christian movements generally are". 'n Kritiese openheid ten opsigte van baie aspekte wat nuut is aan die modeme wêreld is ' $n$ moontlikheid want ook die nuwe is dan creational. Hierdie openheid word as krities bestempel, want verandering word gesien as onderworpe aan die sondeval. Tog skyn dit asof die praktiese uitwerking van die goeie bedoelinge inherent aan Dooyeweerd nie eenduidig geïnterpreteer kan word nie: Dooyeweerd (1957:388-389) beskuldig moderne staatsteorieë daarvan dat hulle nie daarin slaag om 'n struktuur vir die staat daar te stel nie - 'n struktuur wat nie 'n blote snit in die stroom van die geskiedenis is nie. Hiermee word nie by 'n konsep van die essensiële aard van die staat uitgekom nie, maar wel by die modeme Wes-Europese staat soos dit ontwikkel het sedert die Renaissance. Mclntire (1985:104-105) en Wolterstorff (1983:57-58) is van mening dat dit presies ook die probleem met Dooyeweerd se samelewingsteorie is. Die huidige Westerse kultuur word bloot as normatief aanvaar; die sisteem van nasionale state, liberale konstitusionele staatstrukture, die welsynstaat, kapitalisme, die kerngesin en huidige kerkstrukture is vir Dooyeweerd normatief. Wolterstorff betwyfel ook Dooyeweerd se kritiese inset deur te stel dat hy weinig sensitiwiteit toon vir die ingeboude uitbuitende dominasieverhoudings van veral die kapitalistiese wêreldekonomie. Met hierdie oordeel is Dooyeweerd se aanspraak dat hy aan die historisme ontkom, hoogs kontroversieel. 'n Meer simpatieke oordeel sou miskien

$6 \quad$ McIntire (1985:82-83) wys daarop dat hierdie sterk klem van Dooyeweerd verstaan moet word teen die agtergrond van sy oortuiging dat die Westerse kultuur 'n krisis beleef en dat hy toenemend geglo het dat die kem van die krisis geleë is in 'n historisme wat buite beheer geraak het - 'n siekte wat geen vastheid meer moontlik maak nie. 
Swaardmag en lyding - oor die reformatoriese perspektief op staatsgeweld

wees dat Dooyeweerd se siening van historisiteit bloot te eng is en dat ruimte vir 'n groter dinamiek ten opsigte van die wil van God gemaak moet word.

Aan die ander kant is die 'minder rigiede' uitgangspunte van Hart/Wolterstorff ook nie sonder spanninge nie. Twee kritiekpunte lyk veral ter sake:

* Eerstens, Hart (1992a:8-9) se tweede groot probleem met die verchristelikte Platoniese logostradisie is dat dit 'n deïstiese godsbeeld opdring: 'n streng skeiding word gemaak tussen die punt waar God se taak en verantwoordelikhede eindig en waar die mens s'n begin. God verskaf net die orde vir die skepping en die mens het net die verantwoordelikheid om dit met sy rede na te speur en te verwesenlik. Vir Hart (1992a:18-19) is dit egter arbitrêr om te stel dat sommige reëls/wette deur God alleen gemaak word en ander deur die mens. Ons moet God se outoriteit in die hele skepping aanvaar, wat tegelyk beteken dat alle reëls/wette ook gesien moet word as 'n menslike produk. Die verskil tussen 'n Platoniese siening van die wet en die reformatoriese siening is dat laasgenoemde "does give us some responsibility for the criteria we will live by. They are not ready made and already revealed by God" (Hart, 1992a). Hoewel Hart se formulering versigtig is en 'n mens met sy basiese beswaar teen die deïsme kan saamstem, skep hy tog die indruk van 'n oormatige klem op die mens se vermoë om sy eie norme te stel of ontwerp. Volgens Hart $(1992 \mathrm{a}: 17,18,20)$ is ons in Christus vrygemaak "to work out our own salvation in fear and trembling" (Hart, 1992:18) - 'n uitspraak waarin klem gelê word op 'n sterk mate van outonome handeling deur die mens. Dit beteken verder dat ons nie agter een of ander wetsorde kan wegkruip nie maar dat ons self moet uitspel wat goed en sleg is in ons tyd. In plaas daarvan om 'n vaste orde te wil naspeur, het ons die verantwoordelikheid om 'n verlossende moraliteit vir ons tyd te verkondig. Dit beteken dat ons byvoorbeeld vir so iets soos die staat sal moet verduidelik waarom die konsepte swaardmag en geregtigheid as fundamenteel samehorend gesien moet word; die noodsaak hiervoor moet verduidelik word deur die moontlike slegte gevolge te verduidelik indien sake anders gesien word. Indien goeie argumente nie gegee kan word nie, is ons vry om 'n nuwe en ander 
M.F. Heyns

normatiwiteit uit te werk. ${ }^{7}$ So 'n neiging tot menslike outonomie loop natuurlik dieselfde paadjie as die deïsme wat gevolg het op die Platoniese tradisie. Hoewel saamgestem kan word met die klem op menslike verantwoordelikheid, is dit binne die huidige sekulêre klimaat nodig dat die rol van God in ons poging tot kultuurskepping duidelik geartikuleer word (hoewel beslis nie op deistiese wyse nie) anders sal Hy teoreties maklik gemarginaliseer word tot 'n blote stempel op en die legitimering van suiwer menslike skeppinge.

* $\quad$ 'n Tweede beswaar teen die standpunt van Hart/Wolterstorff is dat hul siening van die skeppingsorde eerder 'n funksie is van die oorheersing van die kontemporêre stryd teen lyding as 'n outentiek Christelike motief wat nooit beperk kan word tot net die verlossingsmotief sonder om die skeppingsmotief op gelyke voet te stel nie. Volgens Hart $(1992 \mathrm{a}: 2,3,6)$ het die konsepte orde en rede geeste van destruksie geword toe hulle begin het om op permanente basis die Westerse etos te bepaal en sigself as verlosser van die mens voor te hou en die werklike etos van mededoë te oorskadu. Wat volgens Hart (1992a:20) nodig is, is nie dat orde en die rede wat dit naspeur, afgeskaf word nie, maar dat dit ondergeskik gestel word aan verlossing. Ook moet orde en rede gesien word as net nog een van die gawes van God en nie as 'n onaantasbare gegewe vir tyd en ewigheid nie. Die vermoede bestaan dat ook hulle 'n paradoks inbeweeg wat tot 'n groot mate ooreenkom met die spanning tussen die vaste en dinamiese wat vroeër in die denke van Rorty geïdentifiseer is. Dit is asof Hart $(1992 \mathrm{a}: 17,18,19)$ die ondergeskikte rol wat hy aan die wet toeken onmiddellik terugtrek met die kwalifikasie wat hy daaraan gee: hy stel naamlik dat die mens tog wel verplig is om die goeie (dit is wat seën en vrug dra) na te jaag en die bose (dit wat seermaak, doodmaak, verdruk ens.) te weerstaan deur die skeppingsorde relatief te stel tot "justice, love, peace, and joy ..." (Hart, 1992a:16). Die vraag is egter of geregtigheid, liefde, shalom ensovoorts, nie ook vaste beginsels en dus 'n orde veronderstel nie? Hart is van mening dat die skeppingorde 'n mindere posisie moet inneem maar hy beroep hom tegelyk op 'n soort orde om hierdie ondergeskiktheid van die skeppingsorde te

7 Hart self gebruik die voorbeeld van seksuele moraliteit: ons het die verantwoordelikheid om te motiveer waarom swangerskap, die huwelik en seksuele omgang met mekaar moet saamgaan. 
Sw'aardmag en lyding - oor die reformatoriese perspektief op staatsgeweld

fundeer. Die onderskeid tussen die twee stelle ordes is nie duidelik nie. ${ }^{8}$ Die ooreenkoms met die moderne paradoks waarvolgens 'n universele stryd teen lyding ons dwing om afskeid te neem van enige universele ordes is te duidelik om te ignoreer.

Wolterstorff stuit spesifiek ten opsigte van die staat op 'n soortgelyke paradoks wanneer hy stel dat, hoewel 'n bepaalde instelling (soos die staat) wat hom betref nie ' $n$ vaste taak het nie en dat selfs die administrering van geregtigheid in ' $n$ ander kultuur deur ' $n$ ander instelling as die staat gedoen kan word, daar wel sekere "basic functions regularly performed" binne 'n gemeenskap is (vergelyk Wolterstorff, 1983:62). Vaste take (soos die administrering van geregtigheid) bestaan dus wel. Wat meer is, volgens Wolterstorff (1983:62) is dit so dat "an institution could scarcely be considered a state unless, among other things, it saw to the administration of justice in that society". Hiermee wil Wolterstorff stel dat geregtigheid wel een van die take van die staat is maar nie die enigste nie. Behalwe dat Wolterstorff hier op paradoksale wyse op twee stoele probeer sit (die universele en die kontingente) is die gevaar dat as enige instelling die reg het om alle take te kan verrig, 'n totalitêre staat (dit wil sê 'n staat wat alle sosiale funksies vervul) in beginsel nie af te wys is nie. Wolterstorff gee toe dat ons nie moet toelaat dat sekere instellings alle ander instellings oorheers nie - pluralisme moet wel bevorder word. Staatstotalitarisme sou immers tot die verydeling van menslike lewe lei. Dit is egter nie duidelik hoe die blote stel dat 'die lewe van mense bevorder moet word', sodanige oorheersing veroordeel en gaan verhoed as die bevoegdheid van die staat nie uitgespel is nie.

Dit blyk dat sowel Dooyeweerd as Hart/Wolterstorff vanuit twee fundamentele beginsels vertrek, naamlik dat daar wel 'n goddelike orde vir die skepping (insluitende die staat) bestaan. Hierdie orde is egter geensins

$8 \quad$ Van der Hoeven (1992:3-4) se kritiek is selfs meer spesifiek: hy stel dat dit nie rym dat Hart op een plek stel dat die samevatting van die wet die liefe is en op 'n ander plek dat liefde die wet transendeer nie. Hart (1992b:5) antwoord deur te stel dat die liefde, hoewel gedra deur die wet, nie aan die wet gebind hoef te bly nie, ook die kruis is byvoorbeel 'n draer van liefde. Hierby voeg hy dat liefde nie 'n ander wet word nie omdat liefde verder reik as enige wet. Dit kan Hart toegegee word dat liefde anders as 'n blote wet is; dit is immers primêr 'n aktiwiteit en daarom is dit miskien beter om te praat van die 'wet vir die liefde' as uitleg van die liefdeswet. Dit bewys egter nog lank nie die afwesigheid van 'n wetmatigheid nie. Liefde is ' $n$ konstante opdrag van Godsweë vir alle menslike relasies. 
M.F. Heyns

van dieselfde aard as die Platoniese tradisie van onveranderlike realistiese/verontologiseerde idees/orde wat in die Westerse denke gewild geword het en uiteindelik verwerp en met 'n historistiese nominalisme vervang is nie. Dit blyk verder dat genoemde denknuanses in die reformatoriese tradisie (Dooyeweerd vs. Hart/Wolterstorff) poog om aan albei die uitgangspunte vas te hou maar dat dit tog soms skyn asof na die een of die ander kant oorbeklemtoon word met gevolglike kontradiksies wat in die onderskeie standpunte ingebed is.

Die belangrike konsekwensie vir 'n oordeel oor die inbou van die swaardmag in die orde vir die staat is dat swaardmag/staatsgeweld wel deel van die opdrag/roeping aan regeerders is. Dit beteken dat die norm nie geïdentifiseer word met die vorm wat dit in 'n spesifieke staat/ kultuur/tyd aanneem nie. Tegelyk kan die norm ook nie as 'n rigiedonveranderlike, onafhanklike norm geïnterpreteer word nie. Die norm is 'n manifestasie van God se identifisering met sy skepsele in die tyd. Dit beteken dat die wet nie onafhanklik bestaan van 'n konkrete situasie waarin dit leiding gee aan mense nie. Verder, die eksistensiële moment in normpositivering waarvolgens die mens 'n groot stuk verantwoordelikheid vir die vorm van die staat dra, mag nie deur die idee van 'n konstante struktuur vir die staat onderdruk word nie. Hierdie verantwoordelikheidsmotief, in samehang met die verlossingsmotief - ook in sy modeme artikulasie as die vermyding van pyn en die basiese beswaar teen geweld beteken dat ons veel vryer kan omgaan met die idee van die swaardmag wat vir die staat gegee is as wat baie keer die geval was en is in die Christelike logostradisie. Die swaardmag (hoewel 'n instrument wat lyding veroorsaak) kan toegelaat word as deel van God se leiding aan die mens in die situasie waarin hy leef met die doel om nog groter lyding te voorkom. Daar moet egter ook deurentyd gevra word of dit regtig nodig is dat die swaardmag, as noodwendige instrument wat lyding bring, immer teenwoordig sal wees in die funksionering van die staat.

9 Wolters (1992:5\&16) wys daarop dat die reformatoriese tradisie homself na twee kante toe definieer, naamlik dat die marginalisering van die Bybelse konsep skepping deur die moderne humanisme weerstaan moet word maar dat die versoeking om in dié proses van die Griekse metafisiese tradisie gebruik te maak, weerstaan moet word. Die idee van 'n supra-histories-metafisiese entiteit moet verwerp word maar ook die relatiwistiese ontkenning van alle konstanthede. 


\section{Waarheen met die swaardmag?}

Die argument van die vorige afdeling is dat die swaardmag (staatsgeweld) deel van die struktuur van die staat is maar dat 'struktuur' as sodanig nie op rigiede en Platonies-logosistiese wyse geïnterpreteer kan word nie. Voeg hierby die basiese beswaar teen geweld en die moderne ideaal dat lyding uitgeskakel behoort te word en die vraag na die presiese plek en rol van geweld in die struktuur vir die staat word 'n dringende probleem.

\subsection{Funderende en leidende funksies van die staat}

Die siening van Dooyeweerd kan weereens as invalshoek gebruik word vir 'n verkenning van die reformatoriese visie op hierdie saak. Vir Dooyeweerd (1957:380-381) is dit uit die denkgeskiedenis duidelik dat die staat 'n interne struktuur vertoon waarin die begrippe geregtigheid en die monopolie van die swaardmag albei 'n identiteits- en struktuurgewende rol speel. Die vraag is of die prominente plek wat Dooyeweerd ten opsigte van hierdie aspek aan geweld (swaardmag) binne die struktuur vir die staat gee, gehandhaaf kan word.

Die belangrike vertrekpunt vir die plek wat Dooyeweerd aan die swaardmag gee, is sy standpunt dat 'n dialektiek tussen mag en reg onaanvaarbaar is. Volgens Dooyeweerd (1957:397-399) is die konsekwensie van die historistiese relatiwisme dat die struktuur van die staat in 'n spanningsvolle dialektiek tussen mag en reg verwoord word. Hierdie spanning word vergestalt in teorieë wat die regstaat-idee verdedig teenoor teorieë ten gunste van 'n absolutistiese magstaat. Soms word gepoog om die twee verabsoluteringe in dieselfde teorie te versoen maar dan sal steeds geslinger word tussen die idee van 'n absolutistiese/totalitêre magstaat en die oorbeklemtoning van onvervreembare menseregte wat die soewereine mag van die staat ontken/ondergrawe. Dooyeweerd (1957:400-401) meen dat hy die dialektiek tussen reg en mag kan oorkom deur albei tot identifiserende maar onderskeie funksies van die staat te verklaar funksies wat deur 'n supramodale individualiteitstruktuur vir die staat tot 'n eenheid gebind word. Reg en mag word binne hierdie individualiteitstruktuur onderskeidelik die leidende en funderende funksies genoem.

10 Clouser (1991:222-224) verduidelik die verskille in status van die twee benaminge en die funksies/modaliteite wat ter sprake is, soos volg: die funksie wat die natuurlike materiaal voorsien waaruit 'n kultuurding soos die staat gemaak is, is funderend vir die identiteit daarvan. Dit is egter duidelik dat die volledige kwalifisering van die kultuurding hiermee nie afgehandel is nie. Daar moet nog na 
M.F. Heyns

Die funderende funksie van die staat is volgens Dooyeweerd (1957:404405) die historiese modaliteit. Dit beteken dat die staat, soos ander histories gefundeerde samelewingsverbande, gekenmerk word deur organisering of historiese vorming wat tegelyk 'n vormgewende mag veronderstel (Dooyeweerd, 1957:410-412). Aangesien hierdie fundering egter vir meerdere verbande geld, formuleer Dooyeweerd (1957:413-414) staatsmag, in onderskeid van kerk-, bedryf- of skoolmag, as die "internal monopolistic organization of the power of the sword over a particular cultural area within territorial boundaries" (Dooyeweerd, 1957:414). Die ander funksie wat in die geskiedenis van nadenke oor die staat prominensie ontvang het, die regsfunksie, moet dus volgens Dooyeweerd (1957:434) die leidende funksie van die staat wees. Dit is tog duidelik dat die swaard nie die staat finaal kan kwalifiseer nie; die gewapende magte moet aan die burgerlike regering onderworpe wees om te keer dat die staat nie in ' $n$ georganiseerde bende misdadigers ontaard nie. Die staat se funderende funksie, naamlik die swaardmag, kan dus net begryp word in sy strukturele samehang met sy tipies leidende funksie, naamlik geregtigheid.

Met die erkenning dat die swaardmag nie die staat finaal kan kwalifiseer nie, doen Dooyeweerd implisiet 'n baie belangrike ding: Hy veronderstel naamlik dat staatsgeweld (swaardmag) 'n 'gevaarlike' vermoë is wat baie definitief ingeperk behoort te word. Hierdie veronderstelling sou 'n belangrike argument wees teen die etikettering van Dooyeweerd as 'n legitimis. Tog kan kritiese vrae omtrent Dooyeweerd se inbou van die swaardmag in die staatstruktuur steeds gevra word.

\section{2 'n Onderbeklemtoonde rol vir die swaardmag}

Die eerste kritiese vraag oor die swaardmag as funderende funksie vir die staat sluit aan by Dooyeweerd se weerstand teen die historisme. Een van sy sentrale strategieë is om die reikwydte van historisiteit tot 'n enkele modaliteit te beperk. McIntire (1985:89-90, 92-96) twyfel egter of Dooyeweerd dit regkry: die manier waarop Dooyeweerd die historiese

\footnotetext{
'n funksie gesoek word wat as plan vir die omvorming van die materiaal diens doen en dus die proses van vorming lei; dit is die leidende funksie vir die kultuurding. In die derde plek is die tipe funksie wat die omvorming van die materiaal bepaal ook deel van die kwalifisering van die kultuurding. Hierdie funderende funksie is in die kulturele of historiese modaliteit gelee. Hierdie tweede funderingsfunksie is volgens Dooyeweerd die enigste funderingsfunksie van die staat en soos verder aan verduidelik sal word, is dit 'n kontroversiële standpunt.
} 
aspek van die werklikheid hanteer, dui eerder daarop dat hy van 'n transmodale teorie van historisiteit gebruik behoort te maak; dit wil sê as 'n dimensie wat alle modaliteite omspan. Dooyeweerd byvoorbeeld, kan nie aantoon dat een entiteit eksklusief deur die historiese modaliteit gekwalifiseer word soos wat hy met al die ander modaliteite kan doen nie. Volgens Dooyeweerd is feitlik elke ding wat met menslike kultuur te doen het, in die historiese 'gefundeer'. Dit is ook nie net die mens wat subjek is van die historiese nie. Rotse, plante, diere maak ook tog 'n paalde geskiedenis/ontplooiing van hul eie deur. Die historiese kan dus nie funderend wees net van kultuur nie.

Stoker $(1970: 364,369)$ het ook ontken dat die historiese een modaliteit onder ander modaliteite is. Ook hy plaas historisiteit binne 'n breër visie, naamlik die kosmiese dimensie ${ }^{11}$ van gebeure. Die implikasie hiervan is heel eerste dat die historiese modaliteit as funderende funksie vir die staat nie sal deug nie (Stoker, 1970:296). Amper meer belangrik is die kritiek wat vanuit hierdie visie op Dooyeweerd se siening van dinamiek in die struktuur van samelewingsverbande gemik word: die modaal-vaste en dinamiese word as ineengestrengel gesien (Stoker, 1970:297).

Hierdie kritiek op Dooyeweerd beteken natuurlik nie dat die swaardmag van die staat totaal ongestruktureerd daar uitsien nie. Stoker (1970:296297) byvoorbeeld maak 'n onderskeid tussen drie strukture vir sosiale verbande: die vertikale struktuur word gebied deur die kosmiese dimensie van modaliteite (dit is die vaste identiteit van die staat - MFH). Verder bepaal die vertikale struktuur dat 'n sosiale verband (die staat) ' $n$ leidende (die juridiese) en funderende modaliteit (die fisiese; landgebied) sal hê. Dit is belangrik om op te merk dat hierdie struktuur die klem laat val op die identiteit van die staat en as sodanig is dit nog nie 'n uitspel van die take wat die staat behoort te vervul nie. Hierteenoor is dit veral die kosmiese dimensie van gebeurtenisse wat aan 'n samelewingsverband sy taak uitwys. Funksioneel verkry 'n verband 'n bestemming in onderskeid van sy leidende/funderende identiteit. Die bestemming van die staat is hiervol-

"1 'n Kosmiese dimensie is ' $n$ universele onderskeiding wat 'n oorsig oor die "so te sê onoorsigtelike verskeidenheid" van die werklikheid vanuit 'n bepaalde kant gee (Stoker, 1970:363). Die eerste belangrike onderskeiding tussen dimensies van die kosmos wat Stoker (1970:364) tref, is tussen die vaste en dinamiese. Die kosmiese dimensie van modaliteite is hiervolgens 'n aanduiding van die vaste, en die kosmiese dimensie van gebeurtenisse ' $n$ aanduiding van die dinamiese. 
M.F. Heyns

gens om ' $n$ inter-individuele orde tussen enkelinge onder mekaar, tussen enkelinge en sosiale kringe en tussen sosiale kringe te reël. Die derde struktuur vir sosiale verbande, naamlik horisontale struktuureenheid, bestaan dan veral in laasgenoemde sosiale verhoudings. Op hierdie stadium kom, volgens Stoker (1970:300-301), 'n struktuur van gesaghebbers en gesagonderdane vir die eerste keer ter sprake. Hierdie gesagsverhouding sal in byvoorbeeld die geval van die staat, deur die vaste (dit wil sê geregtigheid in ' $n$ bepaalde landgebied) en die dinamiese kante (staatsgesag word beperk tot die reëling van ' $n$ inter-orde) van die staat gekwalifiseer word. Eers op hierdie stadium word dit duidelik waar mag inpas. Ten einde die taak van die betrokke verband te volvoer word aan alle persone binne so 'n verband mag gegee.

Die betekenis van Stoker se idee van staatsgeweld/swaardmag is dat hy dit eerder binne die dinamiese aard en taak van die staat plaas en nie soseer deel van die staat se identiteit maak nie; dit wil sê die klem val baie sterker op 'n funksionele aanwending van staatsgeweld as op die vaste aard van die staat as gelegitimeerde geweldsinstansie. Die funksionele aanwending van staatsgeweld sal op sy beurt veel sterker die klem kan laat val op die noodsaak om elke daad van geweld te legitimeer. Dit beteken dat staatsgeweld nie as 'n opdrag onafhanklik van ontwikkelinge binne 'n spesifieke staat gesien moet word nie. Hieruit kan afgelei word dat indien omstandighede dit toelaat, die swaardmag heeltemal laat vaar kan word.

\subsection{Funderende funksie/funksies vir die staat?}

Hierdie laaste beklemtoning, naamlik dat staatsgeweld 'n onderbeklemtoonde rol in die identiteit en funksionering van die staat behoort te kry, moet verder gemotiveer word. Meer spesifiek moet gevra word of net die swaardmag as mags- of historiese funksie vir die staat kan/behoort diens te doen. Dooyeweerd (1957:414-416) erken wel dat ander funksies ook fundamentele voorwaardes vir die bestaan van die staat kan wees. Die staat kan byvoorbeeld nie bestaan as dit nie wortel in die morele oortuiging/instemming van die burgers nie, of as die staat nie oor ekonomiese middele beskik om sy mag in werking te stel nie. Hierdie ander magsmiddele is egter, wat Dooyeweerd betref, ondersteunend tot en gekwalifiseerd/gekleur deur die identifiserende taak van die staat, naamlik die monopolistiese organisering van die swaardmag. Vir Dooyeweerd behoort die swaardmag heel duidelik nie tot die kern van die identiteit van enige ander samelewingsverband nie. Dooyeweerd se argument dat net een fun- 
Swaardmag en lyding - oor die reformatoriese perspektief op staatsgeweld

derende aspek vir die staat bestaan, lyk op die oog af maar yl: die swaardmag is immers nie die enigste gelegitimeerde dwang in die vorm van geweld is nie - ouers het naamlik toegang tot die "roede" (Stoker, 1970:405). Clouser (1991:318) - in Dooyeweerdiaanse toonaard - gee wel toe dat kinders in 'n gesin soms ook met dwang gedissiplineer kan word. Hy relativeer hierdie mag van ouers in 'n gesin egter deur te stel dat dit nie volwassenes betrek nie en tweedens, dat die staat steeds die reg het om ouers se dwangmag weg te neem in gevalle waar kinders teen mishandeling beskerm moet word. Hierdie relativering beteken egter steeds nie dat 'n ouer nie gelegitimeer word om geweld te gebruik nie of dat die swaardmag van die staat nie aan soortgelyke beperkende maatreëls onderworpe is nie.

Dit bly dus ' $n$ vraag of ander magsmiddele nie net so 'n belangrike rol in die funksionering van die staat kan speel as die swaardmag nie. In dié verband is dit belangrik om te let op veral twee middele, naamlik die oortuiging van en vrye instemming deur die burgers. Die standpunt wat verdedig sal word is dat oortuiging/instemming nie as absolute alternatiewe tot die swaardmag gestel kan word nie maar beslis ook nie ondergeskik aan die swaardmag is nie.

Hierdie standpunt word onmiddellik duidelik as gekyk word na Van Niekerk (1987:11-14) se onderskeid tussen 'n magstaat en gesagstaat. Hiervolgens gee 'n gesagstaat leiding aan sy burgers deur die maatreëls wat dit tref te beredeneer en legitimeer. Mag, daarteenoor, is die gebruik van dwangmiddele (meesal geweld) om die maghebber se wil te laat geld. 'n Magstaat het sy gesag (dit wil sê sy vermoë om te lei) verloor maar sal steeds sy wil afdwing. Hoewel aantreklik, is hierdie prioriteit wat Van Niekerk aan 'n oorredende gesag gee tog problematies: dit is 'n poging om geweld/swaardmag normatief totaal uit die struktuur van die staat te skakel - die mag/reg-dialektiek is duidelik hier aan't werk. Tog erken Van Niekerk (1987:16) dat die onderskeid tussen 'n gesagstaat en magstaat op die postulering van twee ideaaltipes gebaseer is wat nie in suiwer vorm in die werklikheid voorkom nie. Dit beteken dat ook 'n gesagstaat soms van geweld gebruik sal maak terwyl 'n magstaat sal probeer om sy dade rasioneel te legitimeer. Van Niekerk sou goed doen om oorreding ook, soos geweld, 'n magsmiddel te noem. Indien wel, is die term magstaat soos wat Van Niekerk dit gebruik, misleidend. Wat eerder ter sprake is, is verskillende magsmiddele. 
M.F. Heyns

Van Niekerk se erkenning dat geen staat van vlees en bloed sonder die swaardmag kan klaarkom nie terwyl dit wel die ideaal bly, moet egter enigsins verder verduidelik word. Heel eerste 'n negatiewe argument: argumente waarvolgens alleenlik oortuiging/demokratiese besluitneming as magsmiddele vir die staat aanvaar word, loop hulself in allerlei paradokse vas.

Popper (1968:358-362) byvoorbeeld verset hom teen die idee dat geweld gebruik kan word om 'n uiters belangrike doel (bv. die realisering van 'n utopie) te bereik. Hy vind dit veral problematies dat geweld as middel op grond van die doel rasioneel verklaar kan word maar dat daar geen manier is waarop die rasionaliteit van die doel as sodanig beoordeel kan word nie. Popper (1968:356-357, 362; 1976:97) verduidelik sy voorkeur, naamlik rasionaliteit (oortuiging) as middel, met die argument dat dit meer geneë is tot kompromie aangesien die waarlik rasionele mens weet dat hy nie alwetend is nie en daarom bereid is om by ' $n$ ander te leer. Popper se rasionele oortuiging is self egter nie vry van die gevaar van verabsolutering nie: Popper (1968:357; 1976:99-100) gaan van die paradoksale standpunt uit dat rasionaliteit as sodanig nie rasioneel bewysbaar is nie maar irrasioneel gekies moet word. Wat meer is, daar is perke aan die houding van toleransie: nie-tolerante persone kan nie vir ewig getolereer word nie. Du Toit (1990:109) wys daarop dat die implikasie hiervan is dat Popper geweld sal legitimeer as redelikheid self in gedrang kom.

Hannah Arendt se alternatief vir geweld, naamlik demokratiese besluitneming loop amper dieselfde paadjie. Arendt (1970:49-51, 54, 63-64, 6469) stel dat hoewel demokratiese besluitneming, net soos geweld, 'n magsmiddel is, hulle teenoorgesteldes op 'n kontinuum vorm: as 'n bepaalde groep byvoorbeeld al sterker die gebruik van geweld as opsie oorweeg, dan taan die ondersteuning en gebruik van demokratiese mag. Die normatiewe implikasie van Arendt se visie is hiermee duidelik: indien daarin geslaag kan word om demokratiese mag absoluut te stel, kan die gebruik van geweld tot 'n groot mate uitgeskakel word. Hierdie anatomie van geweld beteken natuurlik ook dat as demokrasie nie moontlik is nie, geweld die noodwendige alternatief is. Soos in die geval van Popper is dit 'n vraag hoedanig 'n demokrasie homself net met demokrasie kan verdedig en wanneer sal ondemokratiese optrede met geweld beantwoord moet word. Ook in hierdie geval kan die 'morele' instemming van die burgery nie die absolute alternatief vir die gebruik van geweld wees nie.

Koers 60(2) 1995:277-306 
Dit moet heelwaarskynlik aanvaar word dat ook geweld tot die struktuur van die staat kan behoort en dat nie een van die prosedures werklik verhef kan word tot dié magsmiddel van die staat nie. Dit is duidelik dat 'n staat wat oormatig van die swaardmag gebruik maak, beslis besig is om sy gesag en inderdaad sy rede tot bestaan en dus identiteit te verloor. Om die waarheid te sê, hoewel die swaard tot die beskikking van die staat is, is dit verkieslik dat nie primêr en beslis nie uitsluitlik daarmee geregeer word nie. Oortuiging/instemming as magte waarmee burgers se samewerking binne die publieke sfeer gemobiliseer word, se vermoë tot dwang is op hul beurt so broos dat erken moet word dat geweld vir die huidige nie uit die regeerproses geskakel kan word nie.

Die oorheersende beklemtoning van Van Niekerk, Popper en Arendt is dat ander magsmiddele as die swaardmag verkieslik is vir die funksionering van die staat. Dit veroorsaak egter paradokse wat dui op 'n middelverabsolutering. Die dialektiek tussen mag en reg is al deel van die verklaring vir hierdie verabsolutering - al drie is ten diepste skepties jeens staatsmag as sodanig. Tog is dit nie 'n summiere afwys van mag nie. 'n Voorkeur vir nie-gewelddadige mag word wel getoon. 'n Nader verklaring vir die afwys van geweldsmag word gevind in die argument van Taylor (1989:8587 ; 155-156) dat die moderne etiese teorie mank gaan aan wat hy 'n prosedure-etiek noem. Dit is die verskynsel waarvolgens moderne etici meen dat etiese besluite en beoordeling gedoen kan word sonder dat ' $n$ substantiewe (inhoudelike) horison van sterk evaluering, soos die ideaal dat lyding verminder moet word, ter sprake kom. In 'n substantiewe etiek word gevra of die konsekwensie van morele keuses ooreenstem met die sterk geëvalueerde agtergrondprentjie wat dit voorafgaan. In die moderne prosedure-etiek is die veronderstelling dat die waarheid/korrektheid van die besluit uitsluitlik gemeet word aan die hand van die betroubaarheid van die prosedure waarvolgens tot die besluit gekom is. Oortuiging of demokratiese besluitneming sal hiervolgens ongemotiveerd as die enigste prosedure vir goeie administrasie voorgehou word. So 'n substansielose etiek is egter 'n vergissing en dit blyk dat morele ideale ook die moderne prosedure-etiek beïnvloed - al is dit op ' $n$ ongeartikuleerde en versluierde wyse. Die artikulering van die motief agter die gebruik van staatsgeweld moet dus vervolgens aandag kry. 
M.F. Heyns

\subsection{Staatsgeweld: 'n noodmoment in die staatstruktuur}

Hierbo is verskillende argumente aangevoer waarom die swaardmag 'n veel meer onderbeklemtoonde plek binne die struktuur vir die staat behoort in te neem as wat iemand soos Dooyeweerd byvoorbeeld van oortuig is. In hierdie afdeling sal 'n laaste argument bygevoeg word, naamlik dat die swaardmag 'n strukturele moment is wat ter wille van die noodsituasie wat die sonde skep, nodig geword het en dat namate die nood van die situasie verminder, die aandrang op die swaardmag ook kleiner word.

In dié verband is Dooyeweerd (1957:402-404) se behandeling van die dialektiese teologie insiggewend. In teenstelling tot laasgenoemde teologie ontken Dooyeweerd dat staatsmag ' $n$ intrinsiek demoniese element in die staatstruktuur veronderstel. Volgens die dialektiese teologie is staatsmag in 'n noodwendige spanning met Christelike naasteliefde en ware gemeenskap. Vir Dooyeweerd is hierdie spanning wat veronderstel is om enige eenduidige en afgewerkte teorie te ontsnap, niks anders as ' $n$ variant van die immanensiefilosofie se basiese dialektiek tussen reg en mag nie. Die dialektiese teologie maak volgens Dooyeweerd veral die fout om mag as strukturele moment van die staat te verwar met die subjektiewe wyse waarop state in die sondige wêreld hul mag misbruik. Dat mag tot die basiese staatstruktuur behoort (dit kan Dooyeweerd sonder meer toegegee word), is een ding maar om daardie mag eksklusief tot die swaardmag te beperk is ' $n$ ander. Dit is nie genuanseerd genoeg om die spanning tussen die ideaal van geweldloosheid en swaardmag bloot tot die historistiese spanning tussen mag en reg te reduseer nie. Dooyeweerd self is heel vaag oor presies hoe die ontstaan en struktuur van die swaardmag teen die agtergrond van die skepping en die sondeval geïnterpreteer moet word. Hy erken wel dat die swaardmag "has been incorporated into the temporal world-order by God because of sin" (Dooyeweerd, 1957:423). Die staat se struktuur is hiervolgens onbepaalbaar as die fundamentele invloed van die sonde daarop nie in ag geneem word nie. Anders gestel, as dit nie vir die sondeval was nie, sou die goddelike orde vir die staat nie die swaardmag ingesluit het nie.

Die kritiese vraag wat Dooyeweerd nie in behandeling neem nie is of die verlossing nie sou beteken dat die swaardmag stelselmatig weer uit die struktuur van die staat behoort te verdwyn namate die skepping herstel word nie. In sy siening van die goddelike reg wat die staat kry om die swaardmag te gebruik, maak Dooyeweerd self 'n snit in die geskiedenis na die sondeval en voor die volledige verlossing/herstel van die koninkryk van 
God - iets wat hy byvoorbeeld teen die historisme met sy dialektiek tussen reg en mag hou. Dit beteken dat wel toegegee kan word dat geweld/swaardmag tot die opdrag van God vir die staat behoort maar, dat tegelyk erken moet word dat dit nie tot God se verlossingsperspektief behoort dat die volledig herstelde staat met geweld moet regeer nie. Die opdrag is dus dat die mens met Hom moet meewerk aan 'n nuwe orde waarin geweld nie meer deel van die staat se struktuur hoef te wees nie.

Laasgenoemde standpunt suggereer dat 'n volledige spanning tussen die basiese beswaar teen geweld en die noodsaak van geweld in sommige situasies nie 'n bevredigende siening kan wees nie. 'n Belangrike wyse waarop hierdie tipe spanning hanteer kan word, is om perspektief te behou op die oorkoepelende motief in 'n bepaalde visie vir kultuurontplooiing. Volgens Taylor (1989:106-107; 1991:11-12, 71-79) hoef daar nie vasgesteek te word by een van die pole (met al die probleme van 'n eensydige visie daaraan verbonde) nie. Nog minder is 'n simple trade-off between advantages and costs die oplossing. Die uitnemender uitweg is om die fundamentele motief waarvan alle eensydighede afhanklik is, na te speur en helder te formuleer. Met hierdie teoretiese uitgangspunt in die agtergrond lyk dit asof ' $n$ versigtige formulering van die skepping-sondeval-verlossingsmotief die reformatoriese voorwaarde is vir 'n eenheidsvisie oor die basiese beswaar teen, maar somtydse noodsaak vir geweld.

Wolters (1988:58-59) se verduideliking van verlossing as 'n herstel van die skepping is hiervoor besonder nuttig. Verlossing as herstel beteken dat daar nie iets nuuts aan die skepping toegevoeg word nie maar wel dat nuwe lewe aan die oorspronklike goeie skepping gegee word. Tog erken hy dat die verlossing enkele nuwe elemente in spel geplaas het wat nie deel was van die oorspronklike skeppingsontwerp nie. Hier word gedink aan reëlings wat deur die sonde genoodsaak word. Hy (Wolters, 1988:59) motiveer verder:

But like scaffolding attached to a house being renovated, or bandages covering a wound, these are all incidental to the main purpose, meant only to serve the process of restoration. In fact, once that purpose is served, they are discardable.

Dit beteken dat iets soos die swaardmag vir tyd en wyl tot die struktuur van die staat gereken kan word as iets wat in diens van die herstel/verlossing van die skepping diens doen: "... salvation brings many things into the lives of God's people that are not solely part of the restoration of creation, and yet that restoration is nonetheless the exclusive 
M.F. Heyns

focus of redemption" (Wolters, 1988:59). So gemotiveer, is die swaardmag nie in beginsel iets wat die moderne verset teen lyding weerspreek nie. (Hierdie verset teen lyding is ook 'n manifestering van die verlossingsmotief.)

Laasgenoemde standpunt is nie vreemd aan die interpretasie van die reformatoriese siening van hoe die swaardmag teen die agtergrond van die skepping-sondeval-verlossingsmotief gehanteer kan word nie. Reeds Calvyn (1991:1833-1835) wat ook aan regerings die reg tot geweld gegee het en ook die reg tot gewelddadige verset erken (Calvyn, 1991:18481859), motiveer staatsgeweld met die argument dat "om die onderdrukking van godvrugtiges ... te straf beteken nie om skade aan te doen en te verdruk nie" (Calvyn, 1991:1834). Om die waarheid te sê, indien 'n regering nie booswigte met die "getrekte swaard" vervolg nie, sal die owerhede hul aan pligsversuim skuldig maak. Aan die ander kant maak Calvyn (1991:18351838) se siening van geweld ook ruimskoots voorsiening vir die basiese beswaar teen geweld wanneer hy waarsku teen die oorhaastige gebruik van geweld - selfs deur owerhede. Calvyn se motivering: rekening moet gehou word met die feit dat misdadigers oortree as gevolg van die algemeen sondige aard van die mens en dat owerhede daarom medelye met die misdadiger moet hê. Calvyn se siening van geweld is beïnvloed deur ' $n$ verlossingsmotief waarin sowel staatsgeweld as noodmaatreël teen die pervertering van die skepping as die beswaar teen lyding 'n belangrike rol speel: onderliggend is 'n prima facie-veroordeling van geweld. Tog veroorsaak die menslike situasie, waaraan sonde geen geringe deel het nie, dat geweld tog in noodsituasies gebruik mag word.

In meer resente formuleringe gebruik Zuidema (1971:284-287, 296-298) implisiet hierdie argument as hy sê dat 'n Christen sy plek moet vind tussen 'n pasifisme wat op gnostiese wyse sy politieke taak op aarde vermy en 'n militarisme wat die verafgoding van en verslawing aan militêre mag en geweld impliseer. Douma (1986:4-5) formuleer dit deur te praat van die feit dat iets soos burgerlike ongehoorsaamheid wat in geweld kan oorgaan "sy plek vind in die spanningsveld tussen ideaal en werklikheid" wat beteken dat mense wat byvoorbeeld burgerlike ongehoorsaamheid pleeg, "geen duiwels is nie, maar ook geen engele nie" (Douma, 1986:5). Heyns (1989:114-115, 134) verduidelik hierdie saak deur 'n verdere onderskeiding: daar moet onderskei word tussen die ordenings- en terapeutiese funksies van die staat waar eersgenoemde (die regsfunksie van die staat) met die skepping gegee is en die terapeutiese funksie 
Su'aardmag en lyding - oor die reformatoriese perspektief op staatsgeweld

(magsmiddele) tot stand gekom het as gevolg van die sondeval. Hierdie twee funksies sou dan met mekaar tot 'n organiese geheel vervleg wees. Tog erken hy dat in 'n sondelose toestand die terapeutiese funksie en sy magsmiddele nie nodig sou gewees het nie. Die implikasie van hierdie siening is dat in die mate waarin daarin geslaag word om die sonde te besweer, magsmiddele oorbodig en selfs ongewens raak.

\section{Samevatting}

Hoe moet die oënskynlike paradoks tussen die basiese beswaar teen geweld en situasies waar geweld geregverdig is (bv. die staat se reg op die swaard) deur 'n reformatoriese perspektief opgelos word? Die moontlikheid wat deur 'n lang tradisie van reformatoriese denke gebied word, is om te argumenteer dat die ideaal van die herstel/verlossing van die skepping dit soms nodig maak dat middele/prosedures soos geweld ingespan kan word.

Hierdie voorsiening wat vir die regverdiging van geweld gemaak word, kan deur oningewydes maklik met die sogenaamde legitimistiese standpunt verwar word: hiervolgens word die swaardmag van die staat verontologiseer tot 'n a-tydse, bonatuurlike entiteit. So 'n siening gee aan staatsgeweld 'n rigiede en onaantasbare aard. Binne die huidige klem op die vermyding van lyding is so 'n legitimistiese siening egter by voorbaat verdag: die klem op die vermyding van lyding gaan hand aan hand met 'n verwerping van die metafisiese realisme. Hierdie moderne motief het inderdaad ook ingang gevind in die reformatoriese tradisie waar dit wel versoenbaar is met die verlossingsmotief. Dit blyk egter dat die skeppingsmotief nie toelaat dat totaal afskeid geneem kan word van die idee van 'n betroubare orde waarbinne ook plek aan die swaardmag gegee word nie. Hierdie orde moet egter gesien word as verseker deur die getrouheid van God en dit moet nie gegrond word op 'n bo-tydse en bo-natuurlike werklikheid nie. Die swaardmag is dus aan die een kant deel van die vaste struktuur van die staat maar, aan die ander kant, is die interpretasie van 'vastheid' iets wat eerder verband hou met getrouheid as met 'n rigiede en onpersoonlike onveranderlikheid.

Hierdie uitgangspunt beteken dat as die swaardmag 'n struikelblok in die getrouheid van God word, dit as van mindere gelang gesien kan word. Hiermee word 'n onderbeklemtoonde rol vir die swaardmag in die staatstruktuur gesuggereer. Dooyeweerd self gee aan die swaardmag 'n prominente plek in die staatstruktuur as hy dit een van die identifiserende funksies van die staat as sodanig maak. Hoewel hierdie prominente plek 
M.F. Heyns

nie in Dooyeweerd se siening van die staat tot 'n onaantasbare posisie vir die swaardmag verhef word nie (dit word beperk deur die leidende funksie van die staat, naamlik geregtigheid), kan enkele kritiese vrae oor die posisie van die swaardmag tog wel gevra word.

Eerstens, Dooyeweerd tipeer die swaardmag as die kultuurvormende taak van die staat en plaas dit sodoende in die kulturele modaliteit. Die siening dat die kulturele as sodanig net tot 'n element in die modale struktuur beperk word, is egter verdag: hier is eerder sprake van 'n transmodale dimensie. Stoker se siening dat die swaardmag eerstens in die kosmiese dimensie van gebeure tuishoort, maar tegelyk beperk word tot 'n ondergeskikte funksionele (en nie identiteitgewende nie) rol, lyk meer in ooreenstemming met die ideaal dat staatsgeweld tog ook gemeet kan word aan die basiese beswaar teen geweld. 'n Tweede argument ter ondersteuning van 'n onderbeklemtoonde rol vir die swaardmag is dat die staat ook oor ander magsmiddele beskik - byvoorbeeld die oortuiging en instemming van die bevolking. Die swaardmag kan hiervolgens nie verhef word tot die enigste belangrike en regmatige magsmiddel van die staat nie. Hierby kan 'n laaste argument gevoeg word, naamlik dat die swaarmag in die struktuur van die staat 'n voorlopige rol het wat meer die aard van 'n noodmaatreël het as deel van die onaantasbare struktuur vir die staat. Dit beteken dat die swaardmag, na gelang van omstandighede in 'n spesifieke staat, ' $n$ sterker of minder beklemtoonde rol kan inneem. Selfs in die geval van 'n sterk rol ten gunste van die swaardmag sal steeds rekening gehou moet word met die basiese beswaar teen geweld en die feit dat die basiese taak van die staat die administrasie van geregtigheid is; albei is norme/argumente wat ' $n$ beperkende rol ten opsigte van die swaardmag te speel het.

Laastens beteken hierdie dialektiese interpretasie dat 'n volledige spanning tussen staatsgeweld en die basiese beswaar teen geweld onnodig is: namate die noodsaak vir staatsgeweld taan as gevolg van die herstel/verlossing van die skepping, kan dit 'n onderbeklemtoonde rol in die staatstruktuur inneem.

\section{Geraadpleegde bronne}

ARENDT, H. 1970. Geweld/macht en onmacht. Utrecht : Spectrum.

CALVYN, J. 1991. Institusie van die Christelike godsdiens. Vierde Deel. Potchefstroom : Calvyn Jubileum Boekefonds.

CHIDESTER, D. 1992. Shots in the Streets - Violence and Religion in South Africa. Cape Town : Oxford University Press. 
Swaardmag en lyding - oor die reformatoriese perspektief op staatsgeweld

CLOUSER, R.A. 1991. The Myth of Religious Neutrality. Notre Dame : University of Notre Dame Press.

COADY, C.A.J. 1986. The Idea of Violence. Journal of Applied Philosophy, $3(1): 3-19$.

DEGENAAR, J. 1990. The Concept of Violence. (In Manganyi, N.C. \& Du Toit, A., eds. Political Violence and the Struggle in South Africa. Halfway House : Southern Books. p. 70-86.)

DOOYEWEERD, H. 1955. A New Critique of Theoretical Thought. Volume II. Amsterdam : Paris.

DOOYEWEERD, H. 1957. A New Critique of Theoretical Thought. Volume III. Amsterdam : Paris.

DOOYEWEERD, H. 1979. Roots of Western Culture. Toronto : Wedge.

DOUMA, J. 1986. Burgerlike ongehoorsaamheid en politieke verantwoordelikheid. Potchefstroom : PU vir CHO. (IRS-studiestuk no. 218.)

DU TOIT, A. 1990. Discourses on Political Violence. (In Manganyi, N.C. \& Du Toit, A., eds. Political Violence and the Struggle in South Africa. Halfway House : Southern Books. p. 87-130.)

DU TOIT, A. 1991. The Claims of Conceptual Analysis: A Reply to David Brooks. South African Journal of Philosophy, 10(4):120-121.

EDGLEY, R. 1974. Reason and Violence: A Fragment of the Ideology of Liberal Intellectuals. (In Körner, S., ed. Practical Reason. New Haven : Yale University Press. p. 113-135.)

GALTUNG, J. 1969. Violence, Peace, and Peace Research. Journal of Peace Research, 6:167-191.

GARVER, N. 1970. What Violence Is. (In Bierman, A.K. \& Gould, J.A., eds. Philosophy for a New Generation. London : Macmillan. p. 353-364.)

GEERTSEMA, H.G. 1991. Contingentie als uitgangspunt - het denken van Richard Rorty. Philosophia Reformata, 56(1):35-61.

HART, H. 1992a. An Ethos of Compassion and the Integrity of Creation. Paper delivered at the 25th Anniversary Conference of the Institute for Christian Studies. Toronto, Ontario, Canada. June 3-6, 1992.

HART, H. 1992b. Reply to Respondents. Paper delivered at the 25th Anniversary Conference of the Institute for Christian Studies. Toronto, Ontario, Canada. June 3-6, 1992.

HEYNS, J.A. 1989. Teologiese etiek - Deel 2/2. Pretoria : N.G. Kerkboekhandel.

HEYNS, M.F. 1994. Geweld en outentisiteit - oor die definiëring, evaluering en legitimering van geweld. Tydskrif vir Christelike Wetenskap, 30(3\&4):91-112.

McINTIRE, C.T. 1985. Dooyeweerd's Philosophy of History. (In McIntire, C.T., ed. The Legacy of Herman Dooyeweerd: Reflections on Critical Philosophy in the Christian Tradition. Lanham : University Press of America. p. 81-116.) 
POPPER, K. 1968. Conjectures and Refutations. New York : Harper Torchbooks.

RORTY, R. 1993. Contingency, Irony and Solidarity. Cambridge : Cambridge University Press.

STOKER, H.G. 1970. Oorsprong en rigting - Band II. Kaapstad : Tafelberg.

TAYLOR, C. 1989. Sources of the Self - the Making of the Modern Identity. Cambridge : Cambridge University Press.

TAYLOR, C. 1991. The Malaise of Modernity. Ontario : Anansi.

VAN DER HOEVEN, J. 1992. Response to H. Hart, Creation Order in Our Philosophical Tradition, Critique and Refinement. Paper delivered at the 25th anniversary Conference of the Institute for Christian Studies. Toronto, Ontario, Canada. June 3-6, 1992.

VAN DER WALT, B.J. 1990. The Calling of Government and Citizen: Where Do We Stand in South Africa at This Stage? (In Reflections on Power and Violence. Potchefstroom : IRS/PU for CHE. p. 155-173.)

VAN NIEKERK, A.A. 1987. Staatsgesag en burgerlike ongehoorsaamheid. (In Van Niekerk, A.A., De Villiers, J.L., Coertzen, P., Du Toit, D.A., reds. Staatsgesag en burgerlike ongehoorsaamheid. Kaapstad : Lux Verbi. p. 719.)

VAN WYK, J.H. 1990. Kerk, teologie en geweld. (In Venster op mag en geweld. Potchefstroom : IRS/PU vir CHO. p. 76-96.)

VENTER, J. 1984. Die strategie van die bom en die bek. Oor die verhouding tussen geweld, ideologie en onderhandeling. (In IRS. Ideologiese stryd in Suider-Afrika. Potchefstroom : PU vir CHO. p. 86-92.)

WOLTERS, A. 1992. Creation Order: An Historical Look at Our Heritage. Paper delivered at the 25th Anniversary Conference of the Institute for Christian Studies. Toronto, Ontario, Canada. June 3-6, 1992.

WOLTERS, A.M. 1988. Creation Regained - Biblical Basics for a Reformational Worldview. Grand Rapids, Michigan : William B. Eerdmans.

WOLTERSTORFF, N. 1983. Until Justice and Peace Embrace. Grand Rapids, Michigan : William B. Eerdmans.

ZUIDEMA, S.U. 1971. Enkele motieven van het anti-militair pacifisme. (In Bingle, H.J.J., e.a. reds. Waarheid en werklikheid - Wysgerige perspektiewe op die werklikheid. Braamfontein, Suid-Afrika : De Jong. p. 283301.) 
Swaardmag en lyding - oor die reformatoriese perspektief op staatsgeweld 